\title{
Case Study of Using Ruqyah Complementary Therapy on a British Muslim Patient with Cluster Headache
}

\author{
Hamidi Abdul Rahman, and Supyan Hussin
}

\section{ABSTRACT}

A case study of a male British Muslim of Pakistani descend with severe cluster headache was presented. The patient only responded to morphine treatment but his condition continued to deteriorate. He resorted to ruqyah complementary therapy, which is based on incantations of the Quran, after seeking advice with a local imam (Islamic cleric). His condition improved significantly and continued to have weekly preventative ruqyah therapy. Since resorting to ruqyah, he has not any morphine treatment and the level and duration of pain have reduced significantly. Ruqyah is popular for the treatment of jinn possession but has also been found to have therapeutic effect on non-mental health problems. The case illustrates that complementing mainstream medicine with ruqyah can bring many benefits especially within the Muslim community. Cooperation between mainstream health service and faith healers is needed.

Keywords: Complementary medicine, jinn possession, Quranic healing, ruqyah.

\section{INTRODUCTION}

Traditional and Complementary Medicine still has relevance and some countries e.g., Malaysia has introduced it to complement the mainstream health system. Ruqyah is an Islamic treatment methodology that is popular amongst Muslims who seek alternative or complementary treatment options for their diseases or disorders.

\section{CASE PRESEntation}

The subject, a 22-year old male British Muslim of Pakistani descend had severe pain in the left eye in May 2019, collapsed, and was taken to A\&E where he was given Entonox gas with the pain level of 10/10 lasting about two hours. Three days later he had another episode with pain level 10/10 lasting for about 2 hours. His heart rate increased from 80 to $120 \mathrm{bpm}$ during the episodes. CT Scan, $\mathrm{X}$-rays and blood tests came out to be normal. He was later diagnosed as having cluster headache. The frequency of episodes increased from twice a week to four times a week by November 2019. The duration of the episodes also increased from two hours to three hours, and he only responded to morphine injections. His condition further deteriorated with additional migraine. He was eventually hospitalized for 2 weeks in January 2020, but his condition was worse after discharged.
Published Online: January 8, 2021

ISSN: $2593-8339$

DOI: $10.24018 /$ ejmed.2021.3.1.635

\section{H. A. Rahman*}

Institute of Malay World and Civilization, Universiti Kebangsaan

Malaysia, Malaysia.

(e-mail: hamidi@ pisang.uk)

S. Hussin

Faculty of Social Science and Humanities, Universiti Kebangsaan Malaysia, Malaysia.

(e-mail: supyan@ ukm.edu.my)

*Corresponding Author

\section{CUltURAL EXPLANATION OF ILLNESS}

The belief in spirits or demons is not uncommon in many cultures. This belief is not only prevalent in third world countries but also in highly developed Western nations. Rather than diminishing, the trend of believing in spirits and demons are on the increase [1]. "Possession trance disorder" as described in ICD-11 is associated with " $a$ marked alteration in the individual's state of consciousness and the individual's customary sense of personal identity is replaced by an external 'possessing' identity and in which the individual's behaviours or movements are experienced as being controlled by the possessing agent." [2]. In Islam, the jinn is accepted as the external possession identity and the term "jinn possession" rather than "spirit possession" or "demonic possession" is used within the Muslim community to refer to the disorder.

In the UK, a Muslim-minority country, the belief in jinn possession is not uncommon amongst Muslims, who made up about $3 \%$ of the population [3]. In the Islamic belief, Allah is the one and only Creator and the rest are His creations. The creations are divided into the Seen and the Unseen. The Seen and Unseen occupies different realms The Unseen realm includes angels and jinn whereas human live in the Seen realm. The belief in the existence of jinn is fundamental in the Islamic faith, and there are evidences from the Quran and Traditions of the Prophet (Hadith) on the existence of jinn [4]. There is even a chapter in the Quran called "The Jinn". This belief is also true in Muslim- 
majority countries. For example, Muslim may attribute jinn as a cause of depression [5]. Despite the therapeutic impact of the various available psychotherapy approaches, some Muslims have been known to use traditional and spiritual healers for the treatment of mental illness, psychosocial, and psychosexual problems [6].

Upon discharged from hospital, the subject's family started to look for alternative methods of treatment based on Islamic practices. Their first contact was a local imam (Muslim cleric). Previous studies showed that imams have influential role in healthcare including assisting in making healthcare decisions [7]. The imam recommended that the subject seek ruqyah therapy, an Islamic Complementary Medicine therapy that has become popular amongst Muslims for the diagnosis and intervention for jinn possession [8]. Ruqyah is a form of treatment derived from Islamic epistemology and ontology. Islamic epistemology derives its sources of knowledge from two sources. The first source being knowledge from logical, intellectual and scientific evidence similar to that of Western epistemology. The second source of knowledge is through divine revelation and through this source arise the believe in different ontology, especially the existence of unseen beings like jinn and angels. Ruqyah is administered through incantations that have to comply with Islamic shariah (Islamic legal system). The incantations are normally the recitation of selected verses from the Quran which is accepted in the Islamic faith as having the miraculous ability to treat diseases and disorders. The incantations can also include supplications or salutations of the Prophet [9]. Ruqyah has shown to have therapeutic effect on the treatment of depression [10]-[12].

Ruqyah has been known to bring benefits to non-Muslims [13]. Ruqyah can result in irrational negative reactions being exhibited by the patient such as aggressive behaviour, screaming, involuntary movements or pulsation of body parts, unconsciousness, screaming, feeling hot, change of personality, vomiting etc. The reactions are associated with the jinn inside the person reacting to the recitations. A previous quantitative study analysed 34 symptoms defined by two international experts on jinn possession and identified 23 significant and 11 less significant symptoms of jinn possession [14]. The subject has two significant symptoms i.e., seeing things and extreme tiredness and one less significant symptom i.e., frequent headaches. It was not possible to make a conclusive diagnosis that the subject had jinn possession based on the few symptoms.

\section{ADMINISTRATION AND EFFECT OF RUQYAH THERAPY}

The subject initially had a session of ruqyah and felt better after the session but still had some headache. He described the relief of pain by ruqyah to be similar to the relief after taking morphine. This was followed by a one-day intensive comprising three sessions of ruqyah two days later. His condition continued to improve after the one-day intensive, but he continued with having manageable episodes of headache. A week later he had a major episode and was taken to hospital but refused to be administered morphine. Instead, he resorted to attending a three-day intensive session of ruqyah three days later where he had nine sessions of ruqyah over the period. He continued to have minor episodes lasting less than 30 minutes with manageable pain level for the next week. Daily single session of ruqyah was carried out for the following two weeks, followed by a single session per week as preventative therapy for the next three months. His condition improved but was still experiencing headache, which he attributed to migraine rather than cluster headache. Towards the end of the period, he had an episode of cluster headache and the frequency of ruqyah was increased to one session daily for the next two weeks followed by weekly preventative ruqyah for the next two months. He did not have any ruqyah session for the next five weeks, and this was followed by a major episode of cluster headache. $\mathrm{He}$ was stable after nine sessions of ruqyah were conducted over three days followed by weekly sessions. He continued to have minor manageable episode occurring after midnight with decreasing severity and duration.

The subject had not had any morphine treatment since having ruqyah i.e., the past 10 months. As his condition has improved, it is unlikely that he will need morphine as a form of treatment. The subject engaged well with the therapy and increased his spirituality by learning and reciting the Quran on a daily basis.

\section{THERAPEUTIC ALLIANCE AND SPIRITUALITY}

Therapeutic alliance also plays an important role in the recover process. The recommendation by the imam helps to remove barriers for seeking complementary treatment, and the ruqyah therapist was also regarded as a trustworthy member of the community. As such, it was easier for the subject to engage in the therapy without any hesitation. Upon advice from the imam, the subject embarked on a spiritual journey, and also started learning how to read the Quran. Despite studies that support the importance of spirituality in health, the implementation in mainstream healthcare system is absent. Patients will normally get the advice from outside the mainstream healthcare system, through their communities.

\section{DISCUSSION}

The role of faith healers has become more popular within the last decade. A study amongst 482 patients in Iraq who were undergoing psychiatric consultations found that $57 \%$ of them went to faith healers before, during or after psychiatric consultations, with $36.9 \%$ believed that the effect of the treatment were acceptable [15]. In the case of the subject, the decision to seek the opinion of the imam was not to avoid modern medicine but was driven by the frustration that modern medicine had been ineffective in the treatment of the cluster headache. Seeking complementary treatment seemed a logical choice. Previous studies have found that complementing modern medicine with ruqyah have increased therapeutic results. In a study on complementing ruqyah with modern medicine with ruqyah 
on a person with major depressive disorder, it was concluded that combined treatments have a sustainable therapeutic benefit that are not seen when only a single method of treatment is administered [16].

The subject is this case study does not suffer from any mental disorder but ruqyah has shown to have therapeutic effect in reducing the impact of the cluster headache, especially in removing the reliance on morphine. Ruqyah has also been known as having therapeutic effect of some cases of physical diseases as in case studies in Indonesia of a person with acute skin diseases and a person with stomach ulcer. Both persons had unsuccessful results after undergoing modern medical treatment but had very significant improvement after ruqyah [17]. A study in Malaysia on five cases of patients with psychological disorders and physical ailments found out that ruqyah brought positive results [18]. Complementary therapy will continue to be attractive and relevant as modern medicine on its own still does not have the solution to every ailment. Calls for cooperation between health professionals and faith healers have frequently been made and it is hoped that the implementation will be a reality.

\section{REFERENCES}

[1] T. C. Thomason, "Possession, Exorcism, and Psychotherapy," Prof Issues Couns., vol. 8, no. 2, 2008.

[2] WHO, "ICD-11 for Mortality and Morbidity Statistics ( (Version : 09/2020))," 2020. [Online]. Available: https://icd.who.int/browse11/1m/en\#/http://id.who.int/icd/entity/1374925579. [Accessed: 07-Oct2020].

[3] N. Khalifa and T. Hardie, "Possession and jinn.," J. R. Soc. Med., vol 98, no. 8, pp. 351-3, Aug. 2005.

[4] D. Haron, Rawatan Penyakit Akibat Sihir. Bandar Baru Bangi: Persatuan Kebajikan dan Pengubatan Islam Malaysia \& Koperasi Darussyifa' Berhad, 2011, ch. 4, pp. 89-103.

[5] S. C. Walpole, M. Dean, H. Allan, C. David, and G. Mirc, "Interventions for treating depression in Muslim Patients: A systematic review.," J. Affect. Disord., Jul. 2012.

[6] F. Hussain and R. Cochrane, "Depression in South Asian Women Living in the UK: A Review of the Literature with Implications for Service Provision," Transcult. Psychiatry, vol. 41, no. 2, pp. 253-270, Jun. 2004

[7] A. I. Padela, A. Killawi, M. Heisler, S. Demonner, and M. D. Fetters, "The role of imams in American Muslim health: perspectives of Muslim community leaders in Southeast Michigan.," J. Relig. Health, vol. 50, no. 2, pp. 359-73, Jun. 2011.

[8] Y. M. Eneborg, "Ruqya Shariya: Observing the rise of a new faith healing tradition amongst Muslims in east London," Ment. Health Relig. Cult., vol. 16, no. 10, pp. 1080-1096, Dec. 2013.

[9] A. Khadher, M. A. Ramli, and N. A. A. Rahman, "Pemahaman Terhadap Aspek Penggunaan Ruqyah Dalam Rawatan Penyakit: Analisis Berasaskan Fiqh al-Hadith imam al-Bukhari," Al-Bayan - J. Qur'an Hadith Stud., vol. 14, pp. 168-205, 2016.

[10] M. M. Afifuddin and O. Nooraini, "The Ruqyah Syar'iyyah Spiritual Method as an Alternative for Depression Treatment," Mediterr. J. Soc. Sci. MCSER Publ., vol. 7, no. 4, pp. 406-411, 2016.

[11] M. W. Mashitah and K. A. Lenggono, "Quran recitation therapy reduces the depression levels of hemodialysis patients," Int. J. Res. Med. Sci., vol. 8, no. 6, p. 2222, 2020.

[12] M. F. Satrianegara and A. Mallongi, "Influence of self ruqyah treatment on cortisol content, depression, and quality of life, spiritual life quality of cancer patients undergoing radiotherapy in Makassar City, Indonesia," Syst. Rev. Pharm., vol. 11, no. 7, pp. 212-218, 2020

[13] C. M. . York, "The effects of ruqya on a non-Muslim: A multiple case study exploration," Inst. Transpers. Psychol., PhD dissertation, Institute of Transpersonal Psychology, Palo Alto, California, 2011

[14] H. A. Rahman, M. K. Mokhtar, A. R. Roseliza-murni, and A. C. Kasim, "Intra and Inter-psyche Conflicts and Analysis of Symptoms of Jinn Possession," Malaysian J. Med. Heal. Sci., vol. 15, no. SUPP1 April 2019, pp. 110-113, 2019.

[15] M. S. Younis, R. K. Lafta, and S. Dhiaa, "Faith healers are taking over the role of psychiatrists in Iraq," Qatar Med. J., vol. 2019, no. 3, pp. 1-8, 2019.

[16] Z. A. Razali, N. A. A. Rahman, and S. Husin, "Complementing the treatment of a major depressive disorder patient with Ruqyah Shar'iyyah therapy: A Malaysian case study," J. Muslim Ment Health, vol. 12, no. 2, 2018.

[17] Adynata and Idris, "Effectiveness Of Ruqyah Syar'iyyah On Physical Disease Treatment In Riau Province," J. Ushuluddin, vol. 24, no. 2 , pp. 211-233, 2016

[18] S. Hussin, N. A. A. Rahman, L. K. On, and M. K. Mokhtar, "Bridging Modern Medicine with Islamic Complementary Medicine: Preliminary Attempts in Malaysian Context," Adv. Sci. Lett., vol. 24 pp. 4820-4823, 2018 .

Rahman, H. A. obtained an MSc in Psychotherapy Studies from the University of Sheffield, United Kingdom in 2013. He is currently pursuing his $\mathrm{PhD}$ at the Institute of Malay World and Civilization, Universiti Kebangsaan Malaysia, Malaysia. He is also the CHAIRMAN of PISANG, a not-for-profit organisation in the United Kingdom specialising in the treatment and research on jinn possession.

Hussin, S. obtained his PhD (Education) from University of Illinois Urbana-Champaign. Currently, he serves as a professor at the Faculty of Social Science and Humanities, Universiti Kebangsaan Malaysia, and an Associate Research Fellow at the Institute of Malay World and Civilization, Universiti Kebangsaan Malaysia. He is the President of Charity Association of the Ethnological-Medical Science of the Malay World and

Complementary Malaysia. 